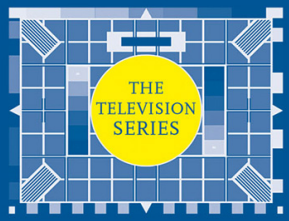

Jack Rosenthal

SUE VICE 


\section{THE \\ TELEVISION SERIES}

Jack Rosenthal

\section{MANCHESTER} 1824

Manchester University Press 


\section{THE \\ TELEVISION SERIES}

series editors

SARAH CARDWELL

JONATHAN BIGNELL

already published

Alan Bennett KARA MCKECHNIE

Alan Clarke DAVE ROLINSON

Andrew Davies SARAH CARDWELL

Tony Garnett STEPHEN LACY

Trevor Griffiths JOHN TULLOCH

Troy Kennedy Martin LEZ COOKE

Terry Nation JONATHAN BIGNELL AND ANDREW O'DAY

Jimmy Perry and David Croft SIMON MORGAN-RUSSELL

Lynda La Plante Julia HALlam 


\section{SUE VICE}

\section{Jack Rosenthal}

\section{Manchester University Press}

MANCHESTER AND NEW YORK

distributed in the United States exclusively by Palgrave Macmillan 
Copyright (C) Sue Vice 2009

The right of Sue Vice to be identified as the author of this work has been asserted by her in accordance with the Copyright, Designs and Patents Act 1988.

Published by Manchester University Press

Oxford Road, Manchester M13 9NR, UK

and Room 400, 175 Fifth Avenue, New York, NY 10010, USA

www.manchesteruniversitypress.co.uk

Distributed in the United States exclusively by

Palgrave Macmillan, 175 Fifth Avenue, New York, NY 10010, USA

Distributed in Canada exclusively by

UBC Press, University of British Columbia, 2029 West Mall,

Vancouver, BC, Canada v6T 1Z2

British Library Cataloguing-in-Publication Data

A catalogue record for this book is available from the British Library

Library of Congress Cataloging-in-Publication Data applied for

ISBN 978 ○ 719077043 hardback

First published 2009

$\begin{array}{llllllllll}18 & 17 & 16 & 15 & 14 & 13 & 12 & 11 & 10 & 09\end{array}$

10987654321

Typeset in Scala with Meta display

by Koinonia, Manchester

Printed in Great Britain

by Biddles Ltd, King's Lynn 